\title{
Bibliocanto
}

100

\section{Biblioteconomia e Jornalismo no BiblioCanto, relato'}

Monteiro², Rejane Lordão rejanelordao@yahoo.com.br

Resumo: Comentários sobre o BiblioCanto, jornal da Biblioteca Central Zila Mamede da Universidade Federal do Rio Grande do Norte, criado em 1994 como veículo de informação e conexão entre a própria Biblioteca e a comunidade universitária, com assuntos relacionados com a biblioteconomia e a cultura.

Palavras-chave: Bibliocanto - Jornal. Biblioteca Central Zila Mamede/UFRN. Universidade Federal do Rio Grande do Norte. Biblioteconomia. Jornalismo.

Considero que o BiblioCanto está para a Biblioteca Central Zila Mamede assim como, Acta Diurna está para o mundo, ambos com histórico de pioneirismo. Comparo a ideia de Gildete Moura com a do romano Júlio César; nas duas criações há o objeto divulgação, evidentemente, cada um em sua época e em seus espaços.

Distingo o BiblioCanto como um informativo cultural, baseada no seu efetivo objetivo, o de veicular para os leitores, acontecimentos, conhecimentos e informações peculiares à biblioteconomia e ao Sistema de Bibliotecas da Universidade do Rio Grande do Norte. O ponto principal é que ele é um espaço de acolhimento para leitores e autores que dele queiram participar e exprimir aspectos da vida cultural e científica da Universidade, do nosso e de outros Estados.

Na origem, em 1994, o jornal foi impresso nos moldes tradicionais (em papel), apesar da popularização dos computadores e da internet, desde 1980. Ressalto que o Sistema de Bibliotecas estava iniciando os procedimentos de informatização das suas ações, conforme registro em matéria do seu primeiro número. Por esta razão, pela carência de mecanismos tecnológicos, o

\footnotetext{
${ }^{1}$ Apresentado durante as Comemorações alusivas ao dia do Bibliotecário: mesa redonda: 21 anos do BiblioCanto, relatos de experiências. 16 mar. 2016.

2 Diretora da Biblioteca Central Zila Mamede, período 1994-1998.
} 


\section{OBibliocanton}

processo da sua montagem era executado por uma empresa contratada, a Textos Informática e a impressão era realizada pela Editora Universitária. Tudo era criteriosamente organizado e contava com jornalistas colaboradores: Marize Castro, no primeiro número e Paulo Augusto no segundo e terceiro número. Houve ainda a determinação de criação do Conselho Editorial composto por: Rejane Lordão Monteiro, Gildete Moura de Figueirêdo, Maria Salete Bezerra Belarmino de Macedo, Maria Lúcia de Sales Cabral Barreto, Ligia de Araújo Alves, Margareth Régia de Lara Menezes e Maria da Saudade Guimarães Araújo de Souza.

O N01 outubro 1994 - exemplar todo dedicado ao LIVRO singulariza homenagens à Zila Mamede, à Biblioteca e a José Olympio. Em seis folhas, apresenta matérias e artigos de Edson Nery da Fonseca, Marize Castro, João Batista de Morais Neto, Carlos Drummond de Andrade e aspas sobre os primeiros passos da automação dos processos do Sistema de Bibliotecas da Universidade Federal do Rio Grande do Norte, titulado "Balcão de informação: rapidez e eficiência para o usuário da BCZM". Iniciava-se a intenção de fazer circular informações, diagramadas em formato jornalístico, para conectar a Biblioteca Central Zila Mamede com a comunidade acadêmica, nos moldes confortáveis da leitura impressa.

v. 2 n.1/2 jan./jun. 1995 - somente oito meses depois da sua primeira tiragem foi publicado o segundo número, com oito folhas, contendo artigos assinadas por: Ilza Matias de Sousa, Edson Nery da Fonseca, Paulo Augusto, Franklin Jorge, Maria do Socorro de Azevedo Borba e Jarbas Martins. "Um canto pra se revelar", utilizei esta frase de Marize Castro como chamamento para o Editorial assinado por mim e nele comento Aurélio Buarque de Holanda sobre a sua explicação para a palavra bibliocanto (chapa dobrada em ângulo reto que ampara livros em estantes), sendo esta a fonte que inspirou o nome do jornal. Cito Gildete Moura de Figueiredo como a mentora do jornal e do seu título. Aproveito a oportunidade para comentar que: "ideias assim ocorrem naquelas pessoas que promovem a instituição através de valorosas contribuições, essencialmente, vindas do coração". Ao escrever o Editorial 


\section{oBibliocantod}

pesou-me a responsabilidade quanto ao que iria consignar, atentando sobre a minha formação em jornalismo. Entre tantas vezes, pensei, com saudade, em Zila Mamede, ela já não estava ali para aplaudir, abraçar ou criticar o intento.

O v.2 n.3 jul./set. 1995 - totalizando dez folhas, arrola artigos assinados por Rosália Paraíso Matta de Paula, Paulo Augusto, Francisco Ivan. Este foi o último número publicado enquanto eu estava à frente da Direção da Biblioteca Central Zila Mamede. Recordo o quão era difícil o patrocínio financeiro, solicitado pela Biblioteca Central à Pró-Reitoria de Administração, para a montagem e editoração de cada tiragem da publicação. Por razões das dificuldades a sua periodicidade, prevista para ser semestral, tornou-se irregular. Gildete Moura, a idealizadora, aposentou-se e perdi a força da sua insistência para manter a publicação corrente, mesmo reconhecendo que já estava consolidada na comunidade acadêmica.

A informatização do SISBI - Sistema de Bibliotecas da UFRN, implantada através de árduo trabalho, possibilitou modernizar e tornar ágeis os seus procedimentos. Em consequência, anos depois, em 2015, o BiblioCanto incluiu-se nesta modernidade, em meios digitais. Avalizo que o jornal em formato eletrônico permite possibilitas múltiplas, priorizo a rapidez da sua disponibilidade para o público, da atualização da informação e o baixo custo da sua produção. Não tenho dúvida de que seja, também, um meio conveniente para a publicidade do próprio Sistema de Bibliotecas e do trabalho desenvolvido pelos seus bibliotecários.

Sinto orgulho sempre que imagino que estive inserida nesses processos. 